\title{
In vitro screening of selected essential oils from medicinal plants acclimated to Benin for their effects on methane production from rumen microbial fermentation
}

\author{
Jacques B. Kouazounde ${ }^{1,2}$, Long Jin ${ }^{1}$, Tim A. McAllister ${ }^{1}$ and Joachim D. Gbenou ${ }^{2 *}$ \\ ${ }^{1}$ Agriculture and Agri-Food Canada, Lethbridge Research Centre, P. O. Box 3000, Lethbridge, AB, T1J 4B, Canada. \\ ${ }^{2}$ Laboratoire de Pharmacognosie et des Huiles Essentielles, Faculté des Sciences et Techniques, Faculté des Sciences \\ de la Santé, Université d'Abomey-Calavi, ISBA Champ de Foire, 01 BP 918, Cotonou, Bénin.
}

Received 2 April, 2015; Accepted 18 February, 2016

\begin{abstract}
Enteric methane production lowers the efficiency of feed utilization in ruminants and contributes to greenhouse gas emissions which are responsible for global climate change. This study examined the effects of nine essential oils (EO) from Citrus aurantifolia, Cymbopogon citratus, Eucalyptus citriodora, Laurus nobilis, Lippia multiflora, Mentha piperita, Ocimum basilicum, Ocimum gratissimum and Zingiber officinalis on enteric methane production in in vitro batch cultures screening experiments using Andropogon gayanus grass. Two in vitro batch culture incubation runs were conducted independently on separate days at two different ranges of dosages: 0 (control), 150, 300, 600 and 1200 $\mathrm{mg} / \mathrm{L}$ inoculum and 0 (control), 25, 50, 100 and $150 \mathrm{mg} / \mathrm{L}$ inoculum. The effects of EO on in vitro gas production, methane production and apparent dry matter disappearance (DMD) were assessed relative to the control containing no additive. $O$. basilicum, $E$. citriodora, $O$. gratissimum and $C$. aurantifolia, significantly inhibited $\left(Z^{\prime}>0\right.$ and relative decrease $\geq 15 \%$ ) enteric methane production ( $g$ DM incubated) relative to control at dosages of $300-1200 \mathrm{mg} / \mathrm{L}$ and $L$. nobilis, $C$. citratus and $M$. piperita significantly decreased it at 600 and $1200 \mathrm{mg} / \mathrm{L}$. A substantial decrease ( $Z^{\prime}>0$ and relative decrease $\left.\geq 15 \%\right)$ in methane production per $\mathrm{g}$ DM incubated was apparent for $Z$. officinalis and $L$. multiflora at dosage of $1200 \mathrm{mg} / \mathrm{L}$. Most EO had globally negligible effects on methane production ( $Z^{\prime} \leq 0$ and relative decrease $<15 \%$ ) at dosages of 25 to $150 \mathrm{mg} / \mathrm{L}$. Substantial decrease in apparent DMD together with gas production (g DM) incubated was observed relatively to the control with Z. officinalis and L. multiflora at $1200 \mathrm{mg} / \mathrm{L}$ and with the remaining $E O$ at 600 and $1200 \mathrm{mg} / \mathrm{L}$. Overall, this screening investigation demonstrated that addition of assayed EO (except $Z$. officinalis and $L$. multiflora) at dosages close to $300 \mathrm{mg} / \mathrm{L}$ seem to potentially decrease enteric methane production with limited negative effects on dry matter digestibility of forage grass in vitro.
\end{abstract}

Key words: Essential oil, in vitro, rumen, digestibility, methane production.

\section{INTRODUCTION}

Methane is known as a potent greenhouse gas and its accumulation in the atmosphere is thought to be a key factor in global anthropogenic warming besides carbon dioxide and nitrous oxide (Intergovernmental Panel on Climate Change, 2013). One of the significant contributions to the increase of methane in the atmospheric 
Table 1. List of medicinal plants (scientific name, common name and registration number) and plant parts from which the essential oils were extracted.

\begin{tabular}{llccc}
\hline Scientific name of plants & Common name & Registration number & Plant part & Yield (\%) \\
\hline Citrus aurantifolia (Christm). Swing & Lime & AP 2086 HNB & Fruit peel & 0.8 \\
Eucalyptus citriodora Hook & Lemon scent & AAC 181 HNB & Leaves & 2.57 \\
Laurus nobilis L. & Laurel & AP 2065 HNB & Leaves & 0.25 \\
Mentha piperita L. & Peppermint & AAC177 HNB & Leaves & 0.7 \\
Ocimum gratissimum L. & African basil & AAC 176 HNB & Leaves & 0.7 \\
Zingiber officinalis Rosc. & Ginger & AP 2095 HNB & Rhizomes & 1.0 \\
\hline
\end{tabular}

concentration is by the rumen microbial fermentation in domestic ruminant livestock (Lassey, 2007). Therefore, the interest in modulating the rumen microbial fermentation occurring in ruminant has been increasing with reduction in enteric methane production being the ultimate target. To this end, a number of strategies were recently explored using products with antimicrobial properties including plant secondary metabolites of enteric fermentation which is mediated by microorganism activity in the rumen (Ribeiro et al., 2015; Satyanagalakshmi et al., 2015). Most plant extracts are considered as safe in animal production owing to their natural source unlike chemical additives and antibiotics. As a result, it has been demonstrated that essential oils (EO), among other researched natural products, can favorably alter rumen microbial fermentation and reduce enteric methane production owing to their antimicrobial activity (Bodas et al., 2012).

Antimicrobial properties of EO depend on their chemical composition, which is a function of plant species, harvesting seasons, geographical origin, analytical methodology and the plant organ used (Burt, 2004). Many EO have been shown to inhibit methane production in in vitro incubations at high doses together with a decrease in total volatile fatty acid concentrations and feed digestion (Benchaar and Greathead, 2011). There is a challenge in identifying EO that could potentially benefit ruminal fermentation and lower methane production. Therefore, this study aimed to screen the effects of EO from medicinal plants acclimated to Benin on methane production from rumen microbial fermentation of Andropogon gayanus grass using in vitro batch cultures. The plants were selected because their EO are edible and commonly used in medicinal pharmacopoeia in Benin.

\section{MATERIALS AND METHODS}

\section{In vitro experimental design and treatment}

The EO were evaluated for their effects on methane production, gas production and apparent dry matter disappearance (DMD) relative to the controls (inoculums plus substrate without $\mathrm{EO}$ ) in in vitro batch cultures using $A$. gayanus grass. Essential oils were tested in an initial screening in a single run as suggested by Secundino et al. (2010) at 4 dosages of 150, 300, 600 and 1200 $\mathrm{mg} / \mathrm{L}$ inoculum (run 1) as used in a previous study (Benchaar and Greathead, 2011), which observed that most EO inhibited methane production at dosages above $300 \mathrm{mg} / \mathrm{L}$. Based on the results from this experiment where apparent DMD and gas production decreased with most EO at dosages between $300-1200 \mathrm{mg} / \mathrm{L}$, all EO were evaluated in a second incubation run at lower dosages of 25, 50, 100 and $150 \mathrm{mg} / \mathrm{L}$ (run 2) to limit their adverse effect on apparent DMD.

Incubation sets containing only inoculum served as blanks and were used to correct fermentation residues, gas and methane production resulting from the inoculum. In the preliminary and second screening assays, a single incubation run was carried out as suggested by Secundino et al. (2010) and each treatment as well as control and blank samples were tested in triplicate.

\section{Essential oils}

Six EO were prepared by processing various parts (leaves, rhizomes or fruit peel) of six medicinal plants (Table 1) as previously described by Baba-Moussa et al. (2012). The plants were collected by the departments of Ouémé (Porto Novo, Sèmè, Djérègbé), Plateau (Kétou) and Zou (Setto) in Benin and were botanically identified by the National Herbarium of Benin where their voucher specimens were deposited. For each EO, appropriate plant fractions to obtain the desired volume were collected from many plants with combination of all collected samples. The EO were extracted from the collected plant materials after $72 \mathrm{~h}$ of airdrying by steam-distillation for 180-240 min using a Clevenger-type apparatus (Clevenger, 1928) and EO composition was analyzed by gas chromatography coupled to mass spectrometry (GC-MS). In steam distillation, vapours of the volatile components were carried from a plant material by steam, which was produced from water contained in a heated round-botton flask. The resultant mixture of steam flow and oil vapour was condensed in a refrigeration tube, and then collected in a Florentine flask where water and oil were separated. A gas chromatograph (DELSI GC 121 G, Type 300 $N^{\circ} 464$, DELSI instruments: 92, Surenes, France) equipped with a flame ionization detector and a capillary column (CP WAX 52 CB made by Chrompack, Middelburg, Netherland; length $25 \mathrm{~m} \times 0.25$ $\mathrm{mm}$ interior diameter, $0.25 \mu \mathrm{m}$ film thickness) was used. GC-MS was performed (model 5970, Hewlett-Packard, Palo Alto, CA, USA)

\section{*Corresponding author. E-mail: gjdjim@yahoo.fr. Tel: (229) 97533551.}


using a DB-5 non-polar capillary column (length $25 \mathrm{~m} \times 0.25 \mathrm{~mm}$ interior diameter) with ionization energy of $70 \mathrm{eV}$. The column temperature was kept at $50^{\circ} \mathrm{C}$ for $5 \mathrm{~min}$ and programmed to subsequently increase at a rate of $5^{\circ} \mathrm{C} / \mathrm{min}$ to $300^{\circ} \mathrm{C}$. Essential oils constituents were identified on the basis of their Kovats retention indices and mass spectral fragmentation, using standards, literature data (Adams, 2001) and an established laboratory data bank (Laboratory of Pharmacognosy and Essential Oils at the University of Abomey-Calavi, Benin).

An additional three EO extracted by hydrodistillation and analyzed by GC-MS as reported in Baba-Moussa et al. (2012) were obtained from the Laboratory of Pharmacognosy and Essential Oils at the University of Abomey-Calavi (UAC), Benin. The main components in these EO were (\%): estragole, 84.98 for O. basilicum; geranial 7.17, thymol 8.46 , eucalyptol 10.09 , and $p-$ cymene 21.89 for L. multiflora; and myrcene 10.78, neral 30.75 , and geranial 39.42 for $C$. citratus.

\section{Fermentation substrate}

The aerial part of $A$. gayanus grass was collected by cutting plants $10 \mathrm{~cm}$ above the soil surface at the flowering stage during July and August 2012 at the pilot farm of the Faculty of Agronomic Science, UAC, Benin (longitudes $1^{\circ}$ and $30^{\circ} 40^{\prime}$ East). The grass was sundried over a period of 3 days followed by oven drying at $60^{\circ} \mathrm{C}$ for 48 h. Grass was then ground through a $1 \mathrm{~mm}$ screen with combination of all the collected samples before use as the fermentation substrate.

\section{Ruminal inoculum and in vitro batch incubations}

Two ruminally fistulated non-lactating cows fed barley grain and barley silage in a DM ratio of 1:3 were used as donors of rumen fluid for the entire study. Cows were cared for in accordance with standards set by the Canadian Council on Animal Care (CCAC, 1993). Rumen fluid was collected $2 \mathrm{~h}$ after the morning feeding by straining rumen contents from four sites within the rumen through four layers of sterilized cheesecloth into pre-warmed insulated containers. Collected rumen fluid was transported immediately to the laboratory under anaerobic conditions, pooled in equal portions and mixed with a mineral buffer (Menke et al., 1979) in 1:2 ratio to prepare the rumen microbial inoculum.

The in vitro batch incubations were conducted as described by Wang et al. (2000). Incubations were performed in $125-\mathrm{mL}$ serum vials pre-loaded with $500 \mathrm{mg}$ of substrate and warmed to $39^{\circ} \mathrm{C}$. Inoculum $(40 \mathrm{~mL})$ was dispensed under a stream of $\mathrm{O}_{2}$-free $\mathrm{CO}_{2}$ and an appropriate amount of each EO was added into the inoculum by using a pipette to obtain the final desired concentration. Vials were immediately sealed and affixed to a rotary shaking incubator (120 revolutions per minute) at $39^{\circ} \mathrm{C}$ for $48 \mathrm{~h}$.

\section{Sampling and analysis}

Gas production from each of the three culture vials used for each treatment as well as control and blank was measured at $6,12,24$ and $48 \mathrm{~h}$ of incubation using a water displacement technique (Fedorak and Hrudey, 1983). Prior to measuring of gas production at each time point, $10 \mathrm{~mL}$ of headspace gas was sampled for methane analysis (Chaves et al., 2006; Wang et al., 2008).

After $48 \mathrm{~h}$ of incubation, each vial was removed from the incubator and its content was transferred into a pre-weighed $50-\mathrm{mL}$ centrifuge tube and centrifuged at $500 \times \mathrm{g}\left(4^{\circ} \mathrm{C}, 10 \mathrm{~min}\right)$ to obtain a solid fraction (fermentation residue) containing undegraded substrate and residual feed particle-associated microbial biomass
(Narvaez et al., 2013). The fermentation residue from each vial was washed with $\mathrm{dH}_{2} \mathrm{O}$ and centrifuged $\left(500 \times \mathrm{g}, 4^{\circ} \mathrm{C}, 10 \mathrm{~min}\right)$ two times, then dried at $50^{\circ} \mathrm{C}$ and weighed to determine apparent DMD (Narvaez et al., 2013).

The substrate was analyzed for dry matter (DM) and organic matter (OM) content as described by Association of Official Analytical Chemists (AOAC, 2003), neutral detergent fiber (NDF) and acid detergent fiber (ADF) as described by Van Soest (1991). Heat-stable $\alpha$-amylase and sodium sulphite were used in NDF procedure and expressed inclusive of residual ash. Combustion analysis (NA2100, Carlo Erba Instruments, Rodano, Milan, Italy) was used to determine $\mathrm{N}$.

\section{Calculations and statistical analysis}

At each incubation time point, cumulative methane produced was calculated (López et al., 2007) and total net gas production per $\mathrm{g}$ of DM incubated (considering the $10 \mathrm{~mL}$ sampled for methane analysis) or methane production per $g$ of DM incubated was estimated by subtracting the mean values of blanks from that of the control and test vials. Net cumulative methane and gas production per $g$ of DM incubated were estimated after $48 \mathrm{~h}$ of incubation. The apparent DMD was calculated as the difference between incubated weight of the substrate and the dry weight of the fermentation residue corrected for residue weight in the blank (Narvaez et al., 2013).

Because the incubation run was not repeated in each screening trial, the statistical evaluation of results from this study was limited. Therefore, the statistical Z' (Z-prime) factor was calculated as 1-3 $\left(\sigma_{\text {test }}+\sigma_{\text {control }}\right) /\left|\mu_{\text {test }}-\mu_{\text {control }}\right|$, where $\sigma$ indicates standard deviation and $\mu$ indicates mean, and it was used to assess the separation between test (EO treatment) and control values regarding net cumulative methane production, net cumulative gas production and apparent DMD after $48 \mathrm{~h}$ of incubation (Secundino et al., 2010). Test and control values were declared overlapping at $Z^{\prime} \leq 0$, whereas both values are different when $Z^{\prime}>0$ (Secundino et al., 2010). As the acceptance criterion required for ' $Z$ ' to be confirmed as a sample with a substantial decrease in methane production was not established as observed by Secundino et al. (2010), the effect of each treatment on methane production relative to the control was expressed as the percentage of induced change (increase or decrease) in methane production as compared to the control using the equation $R=\left(\mu_{\text {test }}-\mu_{\text {control }}\right) \times 100 / \mu_{\text {control }}$ where $R(\%)=$ relative effect of EO on methane production, $\mu_{\text {test }}=$ net cumulative methane production after $48 \mathrm{~h}$ of incubation with a given treatment; $\mu_{\text {control }}=$ net cumulative methane production after $48 \mathrm{~h}$ of incubation from the control (Secundino et al., 2010). Relative decrease (R) in methane production (per $\mathrm{g}$ of $\mathrm{DM}$ incubated) with addition of EO was considered as significant when $Z^{\prime}>0$ and $R$ value was $15 \%$ or higher as Secundino et al. (2010) observed from previous laboratory studies which shows that a plant causing a relative decrease of $15 \%$ or higher can be considered a promising plant additive deserving further investigation.

\section{RESULTS}

\section{Chemical composition of fermentation substrate and essential oils}

The substrate used in this study had nutrient composition ( $\mathrm{g} / \mathrm{kg}$ in DM) of OM 920, NDF 679, ADF 347 and CP 105.

The main components in EO analyzed by GC-MS in the 
Table 2. Main volatile components ( $\geq 1 \%$ ) in plant extracts analyzed by GC-MS.

\begin{tabular}{|c|c|c|c|c|c|}
\hline $\begin{array}{l}\text { Scientific name of } \\
\text { plants }\end{array}$ & $\begin{array}{c}\text { Number of identified } \\
\text { compounds }\end{array}$ & $\begin{array}{l}\text { Oxygenated } \\
\text { compound (\%) }\end{array}$ & Main components & $\%$ & $\begin{array}{c}\text { Kovats retention }^{a} \\
\text { index }\end{array}$ \\
\hline \multirow{7}{*}{ Citrus aurantifolia } & \multirow{7}{*}{34} & \multirow{7}{*}{16.44} & a-Pinene & 1.96 & 935 \\
\hline & & & $\beta$-Pinene & 8.39 & 979 \\
\hline & & & p-Cymene & 14.23 & 1027 \\
\hline & & & Limonene & 51.37 & 1032 \\
\hline & & & $\mathrm{y}$-Terpinene & 1.03 & 1060 \\
\hline & & & $\alpha$-Terpineol & 6.84 & 1198 \\
\hline & & & $\beta$-Bisabolene & 1.31 & 1510 \\
\hline \multirow{9}{*}{ Eucalyptus citriodora } & \multirow{9}{*}{21} & \multirow{9}{*}{52.38} & Citronellal & 76.47 & 1088 \\
\hline & & & Isopulegol & 1.11 & 1191 \\
\hline & & & Citronellol & 3.18 & 1252 \\
\hline & & & Neoisopugenol & 3.98 & 1319 \\
\hline & & & Citronnelyl acetate & 3.13 & 1370 \\
\hline & & & $\mathrm{y}$-Elemene & 1.18 & 1376 \\
\hline & & & Methy leugenol & 2.62 & 1430 \\
\hline & & & Trans-paramenth-3,8 diol & 1.37 & 1435 \\
\hline & & & Cis-paramenth-3,8 diol & 1.06 & 1511 \\
\hline \multirow{8}{*}{ Laurus nobilis } & \multirow{8}{*}{22} & \multirow{8}{*}{59.06} & Oct-1-en-3-ol & 1.75 & 982 \\
\hline & & & Myrcene & 29.09 & 991 \\
\hline & & & p-Cymene & 1.26 & 1026 \\
\hline & & & Limonene & 5.00 & 1031 \\
\hline & & & 1,8-Cineole & 1.87 & 1035 \\
\hline & & & Linalol & 1.95 & 1101 \\
\hline & & & Chavicol & 9.21 & 1255 \\
\hline & & & Eugenol & 42.50 & 1357 \\
\hline \multirow{7}{*}{ Mentha piperita } & \multirow{7}{*}{25} & \multirow{7}{*}{92.51} & Limonene & 1.60 & 1031 \\
\hline & & & Menthone & 28.49 & 1161 \\
\hline & & & Isomenthone & 3.10 & 1168 \\
\hline & & & Neo-menthol & 1.82 & 1173 \\
\hline & & & Menthol & 45.53 & 1184 \\
\hline & & & Piperitone & 6.59 & 1258 \\
\hline & & & Menthyl acetate & 5.73 & 1292 \\
\hline \multirow{14}{*}{ Ocimum gratissimum } & \multirow{14}{*}{39} & \multirow{14}{*}{33.58} & $\alpha$-Thujene & 5.80 & 928 \\
\hline & & & a-Pinene & 1.69 & 935 \\
\hline & & & Myrcene & 4.76 & 991 \\
\hline & & & $\alpha$-Terpinene & 1.25 & 1019 \\
\hline & & & p-Cymene & 19.95 & 1028 \\
\hline & & & Limonene & 1.17 & 1031 \\
\hline & & & $\mathrm{y}$-Terpinolene & 17.52 & 1061 \\
\hline & & & Terpinen-4-ol & 1.09 & 1183 \\
\hline & & & Thymol & 27.56 & 1295 \\
\hline & & & $\alpha$-Selinene & 2.81 & 1495 \\
\hline & & & Caryophyllene oxide & 1.73 & 1588 \\
\hline & & & a-Pinene & 3.70 & 935 \\
\hline & & & Camphene & 10.79 & 952 \\
\hline & & & $\beta$-Phellandrene & 5.00 & 1033 \\
\hline
\end{tabular}


Table 2. Contd.

\begin{tabular}{|c|c|c|c|c|c|}
\hline \multirow[t]{8}{*}{ Zingiber officinalis } & 35 & 12.59 & 1,8-Cineole & 4.12 & 1035 \\
\hline & & & Terpinen-4-ol & 1.31 & 1183 \\
\hline & & & Geranial & 1.94 & 1269 \\
\hline & & & ar-Curcumene & 11.64 & 1484 \\
\hline & & & $\alpha$-Zingiberene & 19.16 & 1498 \\
\hline & & & y-Bulgarene & 8.12 & 1505 \\
\hline & & & $\beta$-Bisabolene & 7.17 & 1511 \\
\hline & & & $\beta$-Sesquiphellandrene & 8.57 & 1527 \\
\hline
\end{tabular}

current study are presented in Table 2. The EO Citrus aurantifolia mainly contained limonene $(51.37 \%)$ and $p$ cymene (14.23\%). The major compound in Eucalyptus citriodora was citronellal $(76.47 \%)$. Those in Z . officinalis were camphene $(10.79 \%)$, ar-curcumene $(11.64 \%)$ and a-zingiberene (19.16\%). Laurus nobilis was chiefly rich in chavicol (9.21\%), myrcene (29.09\%) and eugenol $(42.50 \%)$. Mentha piperita mainly contained menthone $(28.49 \%)$ and menthol (45. 53\%). The abundant components in $O$. gratissimum were $\mathrm{Y}$-terpinolene (17.52\%), p-cymene (19.95\%) and thymol (27.56\%).

\section{Effects of essential oils on in vitro rumen microbial fermentation}

\section{Incubation run 1}

Off all the EO, O. basilicum, E. citriodora, O. gratissimum and $C$. aurantifolia significantly inhibited $\left(Z^{\prime}>0\right.$ and relative decrease $\geq 15 \%$ ) methane production per $g$ dry matter (DM) incubated at dosages of $300-1200 \mathrm{mg} / \mathrm{L}$, whereas apparent DMD and gas production per g DM incubated were decreased $\left(Z^{\prime}>0\right)$ mainly at 600 and $1200 \mathrm{mg} / \mathrm{L}$ relative to the control (Table 3 ). A substantial decrease ( $Z^{\prime}>0$ and relative decrease $\geq 15 \%$ ) in methane production per g DM incubated was apparent together with a reduction ( $\left.Z^{\prime}>0\right)$ in apparent $D M D$ and gas production per $g$ DM incubated for $L$. nobilis, $C$. citratus and M. piperita mainly at dosages of $600-1200$ $\mathrm{mg} / \mathrm{L}$. Z. officinalis and L. multiflora significantly inhibited ( $Z^{\prime}>0$ and relative decrease $\geq 15 \%$ ) methane production per $\mathrm{g}$ DM incubated at dosage of $1200 \mathrm{mg} / \mathrm{L}$ together with a reduction $\left(Z^{\prime}>0\right)$ in apparent $D M D$ and gas production per $\mathrm{g}$ DM incubated at $1200 \mathrm{mg} / \mathrm{L}$.

\section{Incubation run 2}

Most EO had globally negligible effects on methane production ( $Z^{\prime} \leq 0$ and relative decrease $<15 \%$ ) at dosages of 25 to $150 \mathrm{mg} / \mathrm{L}$ (Table 4). At such dosages, EO treatments and control were overlapping $\left(Z^{\prime} \leq 0\right)$ regarding apparent DMD and gas production per g DM incubated.

\section{DISCUSSION}

\section{Chemical composition of essential oils}

Results from the present study reveal the specificity in qualitative and quantitative composition of the EO from each plant species. Essential oil constituents of a given plant species may vary depending on harvesting seasons, geographical origin, analytical methodology and the part of the plant that they are extracted from (Burt, 2004). This may explain the divergence between the chemical composition of EO analyzed in the present study and that previously reported for their chemotypes (Benchaar et al., 2008; Cimanga et al., 2002; Marzouki et al., 2009). For example, a previous report (Marzouki et al., 2009) from Tunisia observed 1,8-cineole, a-terpinyl acetate and methyl eugenol as main components in the L. nobilis chemotype. Benchaar et al. (2008) reported camphene (14.1\%), ar-curcumene (14.5\%) and $\beta$ bisadolene $(22.1 \%)$ as the major compounds in $Z$. officinalis. Similarly to this study, $O$. gratissimum from Democratic Republic of Congo was a thymol type, but it contained more thymol (53.2\%) and less p-cymene (7.3\%) (Cimanga et al., 2002). Cimanga et al. (2002) also identified eugenol and $\mathrm{y}$-terpinene as main components in $O$. gratissimum chemotype, whereas $\mathrm{y}$-terpinolene was absent. Iscan et al. (2002) identified menthol and menthone as major components in four chemotypes of $M$. piperita, but their concentrations were less than those found for $M$. piperita in the present study. A concentration of $53.53 \%$ was reported by Javari et al. (2011) for limonene in $C$. aurantifolia from Iran, which agrees with the results of the present study. Alpha terpineol and $y$ terpinene are among other major components thought to be responsible for the antimicrobial properties of $C$. aurantifolia, but their concentrations were higher in the previous study than in the present study. The chemotype of E. citriodora from Democratic Republic of Congo was found to contain $72.7 \%$ citronellal (Cimanga et al., 2002), 
Table 3. Effects of essential oils (150-1200 mg/L) on gas production, methane production and apparent dry matter disappearance after 48 of in vitro incubation.

\begin{tabular}{|c|c|c|c|c|c|c|c|c|}
\hline Additive & $\begin{array}{l}\text { Dosages } \\
\text { (mg/L) }\end{array}$ & $\begin{array}{c}\text { GP } \\
(\mathrm{mL} / \mathrm{g} \\
\mathrm{DM})\end{array}$ & $\begin{array}{l}\text { Z' factor } \\
\text { for GP }\end{array}$ & $\begin{array}{c}\text { Methane } \\
(\mathrm{mL} / \mathrm{g} \\
\mathrm{DM}) \\
\end{array}$ & $\begin{array}{l}\text { ' factor } \\
\text { for } \\
\text { methane }\end{array}$ & $\begin{array}{c}\text { Change in } \\
\text { methane relative } \\
\text { to } \mathrm{CT}(\%)\end{array}$ & $\begin{array}{l}\text { Apparent } \\
\text { DMD } \\
(\mathbf{g} / \mathbf{k g}) \\
\end{array}$ & $\begin{array}{l}\text { Z' factor for } \\
\text { apparent } \\
\text { DMD }\end{array}$ \\
\hline Control & 0 & 160.4 & - & 44.4 & & - & 456.8 & - \\
\hline \multirow{4}{*}{ Ocimum basilicum } & 150 & 154.9 & $Z^{\prime} \leq 0$ & 40.0 & $Z^{\prime} \leq 0$ & -10.0 & 424.7 & $Z^{\prime} \leq 0$ \\
\hline & 300 & 133.7 & $Z^{\prime} \leq 0$ & $36.2^{*}$ & $Z^{\prime}>0$ & -18.5 & 355.7 & $Z^{\prime} \leq 0$ \\
\hline & 600 & 104.2 & $Z^{\prime}>0$ & $30.3^{*}$ & $Z^{\prime}>0$ & -31.8 & 244.1 & $Z^{\prime}>0$ \\
\hline & 1200 & 52.2 & $Z^{\prime}>0$ & $22.8^{*}$ & $Z^{\prime}>0$ & -48.6 & 69.6 & $Z^{\prime}>0$ \\
\hline \multirow{4}{*}{$\begin{array}{l}\text { Cymbopogon } \\
\text { citratus }\end{array}$} & 150 & 154.2 & $Z^{\prime} \leq 0$ & 38.7 & $Z^{\prime} \leq 0$ & -12.8 & 428.2 & $Z^{\prime} \leq 0$ \\
\hline & 300 & 155.9 & $Z^{\prime} \leq 0$ & 37.6 & $Z^{\prime} \leq 0$ & -15.4 & 429.0 & $Z^{\prime} \leq 0$ \\
\hline & 600 & 115.0 & $Z^{\prime}>0$ & $33.7^{*}$ & $Z^{\prime}>0$ & -24.1 & 288.5 & $Z^{\prime}>0$ \\
\hline & 1200 & 82.0 & $Z^{\prime}>0$ & $28.6^{*}$ & $Z^{\prime}>0$ & -35.5 & 175.3 & $Z^{\prime}>0$ \\
\hline \multirow{4}{*}{$\begin{array}{l}\text { Eucalyptus } \\
\text { citriodora }\end{array}$} & 150 & 159.3 & $Z^{\prime} \leq 0$ & 38.8 & $Z^{\prime} \leq 0$ & -12.6 & 441.7 & $Z^{\prime} \leq 0$ \\
\hline & 300 & 113.6 & $Z^{\prime}>0$ & $33.9^{*}$ & $Z^{\prime}>0$ & -23.7 & 282.8 & $Z^{\prime}>0$ \\
\hline & 600 & 123.6 & $Z^{\prime}>0$ & $33.0^{*}$ & $Z^{\prime}>0$ & -25.8 & 316.0 & $Z^{\prime}>0$ \\
\hline & 1200 & 60.2 & $Z^{\prime}>0$ & $27.3^{*}$ & $Z^{\prime}>0$ & -38.4 & 63.7 & $Z^{\prime}>0$ \\
\hline \multirow{4}{*}{$\begin{array}{l}\text { Ocimum } \\
\text { gratissimum }\end{array}$} & 150 & 153.3 & $Z^{\prime} \leq 0$ & 38.5 & $Z^{\prime} \leq 0$ & -13.4 & 425.6 & $Z^{\prime} \leq 0$ \\
\hline & 300 & 136.4 & $Z^{\prime} \leq 0$ & $35.4^{*}$ & $Z^{\prime}>0$ & -20.3 & 347.6 & $Z^{\prime} \leq 0$ \\
\hline & 600 & 80.9 & $Z^{\prime}>0$ & $28.0^{*}$ & $Z^{\prime}>0$ & -37.0 & 170.3 & $Z^{\prime}>0$ \\
\hline & 1200 & 39.7 & $Z^{\prime}>0$ & $23.6^{*}$ & $Z^{\prime}>0$ & -46.9 & 81.4 & $Z^{\prime}>0$ \\
\hline \multirow{4}{*}{ Citrus aurantifolia } & 150 & 162.0 & $Z^{\prime} \leq 0$ & 38.2 & $Z^{\prime} \leq 0$ & -14.1 & 439.5 & $Z^{\prime} \leq 0$ \\
\hline & 300 & 149.4 & $Z^{\prime} \leq 0$ & $37.1^{*}$ & $Z^{\prime}>0$ & -16.5 & 384.8 & $Z^{\prime} \leq 0$ \\
\hline & 600 & 130.9 & $Z^{\prime}>0$ & $32.3^{*}$ & $Z^{\prime}>0$ & -27.3 & 463.6 & $Z^{\prime}>0$ \\
\hline & 1200 & 60.8 & $Z^{\prime}>0$ & $25.0^{*}$ & $Z^{\prime}>0$ & -43.8 & 167.5 & $Z^{\prime}>0$ \\
\hline \multirow{4}{*}{ Lippia multiflora } & 150 & 160.1 & $Z^{\prime} \leq 0$ & 37.5 & $Z^{\prime} \leq 0$ & -15.5 & 430.3 & $Z^{\prime} \leq 0$ \\
\hline & 300 & 163.7 & $Z^{\prime} \leq 0$ & 39.4 & $Z^{\prime} \leq 0$ & -11.3 & 432.0 & $Z^{\prime} \leq 0$ \\
\hline & 600 & 152.8 & $Z^{\prime} \leq 0$ & 37.7 & $Z^{\prime} \leq 0$ & -15.2 & 374.6 & $Z^{\prime} \leq 0$ \\
\hline & 1200 & 101.3 & $Z^{\prime}>0$ & $31.9^{*}$ & $Z^{\prime}>0$ & -28.2 & 209.7 & $Z^{\prime}>0$ \\
\hline \multirow{4}{*}{ Laurus nobilis } & 150 & 161.3 & $Z^{\prime} \leq 0$ & 39.6 & $Z^{\prime} \leq 0$ & -10.8 & 430.9 & $Z^{\prime} \leq 0$ \\
\hline & 300 & 160.8 & $Z^{\prime} \leq 0$ & 37.8 & $Z^{\prime} \leq 0$ & -15.0 & 399.8 & $Z^{\prime} \leq 0$ \\
\hline & 600 & 133.9 & $Z^{\prime}>0$ & $35.2^{*}$ & $Z^{\prime}>0$ & -20.6 & 254.3 & $Z^{\prime}>0$ \\
\hline & 1200 & 61.8 & $Z^{\prime}>0$ & $26.9^{*}$ & $Z^{\prime}>0$ & -39.5 & 62.7 & $Z^{\prime}>0$ \\
\hline \multirow{4}{*}{ Zingiber officinalis } & 150 & 162.3 & $Z^{\prime} \leq 0$ & 38.3 & $Z^{\prime} \leq 0$ & -13.8 & 431.1 & $Z^{\prime} \leq 0$ \\
\hline & 300 & 163.2 & $Z^{\prime} \leq 0$ & 38.8 & $Z^{\prime} \leq 0$ & -12.5 & 399.9 & $Z^{\prime} \leq 0$ \\
\hline & 600 & 154.6 & $Z^{\prime} \leq 0$ & 37.7 & $Z^{\prime} \leq 0$ & -15.1 & 328.4 & $Z^{\prime} \leq 0$ \\
\hline & 1200 & 139.9 & $Z^{\prime}>0$ & $35.8^{*}$ & $Z^{\prime}>0$ & -19.4 & 274.2 & $Z^{\prime}>0$ \\
\hline \multirow{4}{*}{ Mentha piperita } & 150 & 164.0 & $Z^{\prime} \leq 0$ & 38.7 & $Z^{\prime} \leq 0$ & -12.9 & 455.4 & $Z^{\prime} \leq 0$ \\
\hline & 300 & 154.4 & $Z^{\prime} \leq 0$ & 37.5 & $Z^{\prime} \leq 0$ & -15.6 & 475.5 & $Z^{\prime} \leq 0$ \\
\hline & 600 & 128.0 & $Z^{\prime} \leq 0$ & $34.3^{*}$ & $Z^{\prime}>0$ & -22.8 & 316.7 & $Z^{\prime}>0$ \\
\hline & 1200 & 62.2 & $Z^{\prime}>0$ & $26.5^{\star}$ & $Z^{\prime}>0$ & -40.4 & 86.2 & $Z^{\prime}>0$ \\
\hline
\end{tabular}

CT: Control, DMD: dry matter disappearance, GP: cumulative gas production, *mean value for an additive differs significantly (relative decrease $\geq 15 \%$ ) from the control within the column. 
Table 4. Effects of essential oils $(25-150 \mathrm{mg} / \mathrm{L})$ on gas production, methane production and apparent dry matter disappearance after $48 \mathrm{~h}$ of in vitro incubation.

\begin{tabular}{|c|c|c|c|c|c|c|c|c|}
\hline Additive & $\begin{array}{c}\text { Dosages } \\
\text { (mg/L) }\end{array}$ & $\begin{array}{c}\text { GP } \\
(\mathrm{mL} / \mathrm{g} \\
\mathrm{DM})\end{array}$ & $\begin{array}{c}Z^{\prime} \\
\text { factor } \\
\text { for GP }\end{array}$ & $\begin{array}{c}\text { Methane } \\
(\mathrm{mL} / \mathrm{g} \\
\mathrm{DM})\end{array}$ & $\begin{array}{l}Z^{\prime} \text { factor } \\
\text { for } \\
\text { methane }\end{array}$ & $\begin{array}{c}\text { Change in } \\
\text { methane } \\
\text { relative to } \mathrm{CT} \\
(\%)\end{array}$ & $\begin{array}{l}\text { DMD } \\
(\mathbf{g} / \mathbf{k g})\end{array}$ & $\begin{array}{l}\text { Z' factor } \\
\text { for DMD }\end{array}$ \\
\hline Control & 0 & 205.5 & - & 22.8 & & - & 463.9 & - \\
\hline \multirow{4}{*}{ Ocimum basilicum } & 25 & 184.9 & $Z^{\prime} \leq 0$ & 20.1 & $Z^{\prime} \leq 0$ & -11.6 & 433.4 & $Z^{\prime} \leq 0$ \\
\hline & 50 & 189.9 & $Z^{\prime} \leq 0$ & 21.1 & $Z^{\prime} \leq 0$ & -7.6 & 447.0 & $Z^{\prime} \leq 0$ \\
\hline & 100 & 177.6 & $Z^{\prime} \leq 0$ & 19.9 & $Z^{\prime} \leq 0$ & -12.5 & 433.7 & $Z^{\prime} \leq 0$ \\
\hline & 150 & 148.2 & $Z^{\prime}>0$ & 19.0 & $Z^{\prime} \leq 0$ & -16.4 & 429.6 & $Z^{\prime} \leq 0$ \\
\hline \multirow{4}{*}{ Cymbopogon citratus } & 25 & 198.2 & $Z^{\prime} \leq 0$ & 21.1 & $Z^{\prime} \leq 0$ & -7.2 & 451.3 & $Z^{\prime} \leq 0$ \\
\hline & 50 & 205.4 & $Z^{\prime} \leq 0$ & 22.5 & $Z^{\prime} \leq 0$ & -1.3 & 447.5 & $Z^{\prime} \leq 0$ \\
\hline & 100 & 199.8 & $Z^{\prime} \leq 0$ & 21.8 & $Z^{\prime} \leq 0$ & -4.1 & 454.1 & $Z^{\prime} \leq 0$ \\
\hline & 150 & 200.3 & $Z^{\prime} \leq 0$ & 20.5 & $Z^{\prime} \leq 0$ & -10.2 & 449.2 & $Z^{\prime} \leq 0$ \\
\hline \multirow{4}{*}{ Eucalyptus citriodora } & 25 & 201.0 & $Z^{\prime} \leq 0$ & 20.5 & $Z^{\prime} \leq 0$ & -9.9 & 436.3 & $Z^{\prime} \leq 0$ \\
\hline & 50 & 203.0 & $Z^{\prime} \leq 0$ & 23.1 & $Z^{\prime} \leq 0$ & 1.5 & 451.5 & $Z^{\prime} \leq 0$ \\
\hline & 100 & 187.6 & $Z^{\prime} \leq 0$ & 19.2 & $Z^{\prime} \leq 0$ & -15.9 & 432.9 & $Z^{\prime} \leq 0$ \\
\hline & 150 & 203.9 & $Z^{\prime} \leq 0$ & 23.3 & $Z^{\prime} \leq 0$ & 2.3 & 434.7 & $Z^{\prime} \leq 0$ \\
\hline \multirow{4}{*}{ Ocimum gratissimum } & 25 & 209.6 & $Z^{\prime} \leq 0$ & 22.4 & $Z^{\prime} \leq 0$ & -1.6 & 456.7 & $Z^{\prime} \leq 0$ \\
\hline & 50 & 205.6 & $Z^{\prime} \leq 0$ & 21.9 & $Z^{\prime} \leq 0$ & -4.0 & 423.1 & $Z^{\prime} \leq 0$ \\
\hline & 100 & 197.4 & $Z^{\prime} \leq 0$ & 19.4 & $Z^{\prime} \leq 0$ & -14.9 & 417.9 & $Z^{\prime} \leq 0$ \\
\hline & 150 & 199.3 & $Z^{\prime} \leq 0$ & 20.6 & $Z^{\prime} \leq 0$ & -9.6 & 446.3 & $Z^{\prime} \leq 0$ \\
\hline \multirow{4}{*}{ Citrus aurantifolia } & 25 & 204.1 & $Z^{\prime} \leq 0$ & 21.0 & $Z^{\prime} \leq 0$ & -7.8 & 467.0 & $Z^{\prime} \leq 0$ \\
\hline & 50 & 207.2 & $Z^{\prime} \leq 0$ & 22.1 & $Z^{\prime} \leq 0$ & -3.1 & 468.1 & $Z^{\prime} \leq 0$ \\
\hline & 100 & 197.2 & $Z^{\prime} \leq 0$ & 18.6 & $Z^{\prime} \leq 0$ & -18.2 & 462.8 & $Z^{\prime} \leq 0$ \\
\hline & 150 & 207.7 & $Z^{\prime} \leq 0$ & 20.8 & $Z^{\prime} \leq 0$ & -8.5 & 461.3 & $Z^{\prime} \leq 0$ \\
\hline \multirow{4}{*}{ Lippia multiflora } & 25 & 204.6 & $Z^{\prime} \leq 0$ & 21.0 & $Z^{\prime} \leq 0$ & -8.0 & 466.2 & $Z^{\prime} \leq 0$ \\
\hline & 50 & 208.2 & $Z^{\prime} \leq 0$ & 23.4 & $Z^{\prime} \leq 0$ & 2.7 & 477.7 & $Z^{\prime} \leq 0$ \\
\hline & 100 & 205.5 & $Z^{\prime} \leq 0$ & 22.0 & $Z^{\prime} \leq 0$ & -3.6 & 450.2 & $Z^{\prime} \leq 0$ \\
\hline & 150 & 206.5 & $Z^{\prime} \leq 0$ & 22.2 & $Z^{\prime} \leq 0$ & -2.7 & 471.8 & $Z^{\prime} \leq 0$ \\
\hline \multirow{4}{*}{ Laurus nobilis } & 25 & 203.0 & $Z^{\prime} \leq 0$ & 21.2 & $Z^{\prime} \leq 0$ & -6.7 & 459.1 & $Z^{\prime} \leq 0$ \\
\hline & 50 & 202.5 & $Z^{\prime} \leq 0$ & 23.3 & $Z^{\prime} \leq 0$ & 2.2 & 477.7 & $Z^{\prime} \leq 0$ \\
\hline & 100 & 198.5 & $Z^{\prime} \leq 0$ & 21.7 & $Z^{\prime} \leq 0$ & -4.5 & 438.5 & $Z^{\prime} \leq 0$ \\
\hline & 150 & 193.2 & $Z^{\prime} \leq 0$ & 22.5 & $Z^{\prime} \leq 0$ & -1.3 & 425.3 & $Z^{\prime} \leq 0$ \\
\hline \multirow{4}{*}{ Zingiber officinalis } & 25 & 200.3 & $Z^{\prime} \leq 0$ & 22.5 & $Z^{\prime} \leq 0$ & -1.3 & 473.5 & $Z^{\prime} \leq 0$ \\
\hline & 50 & 198.7 & $Z^{\prime} \leq 0$ & 22.8 & $Z^{\prime} \leq 0$ & -0.1 & 472.8 & $Z^{\prime} \leq 0$ \\
\hline & 100 & 196.7 & $Z^{\prime} \leq 0$ & 22.0 & $Z^{\prime} \leq 0$ & -3.3 & 460.9 & $Z^{\prime} \leq 0$ \\
\hline & 150 & 194.2 & $Z^{\prime} \leq 0$ & 21.2 & $Z^{\prime} \leq 0$ & -7.1 & 455.7 & $Z^{\prime} \leq 0$ \\
\hline \multirow{4}{*}{ Mentha piperita } & 25 & 194.5 & $Z^{\prime} \leq 0$ & 20.3 & $Z^{\prime} \leq 0$ & -10.9 & 481.2 & $Z^{\prime} \leq 0$ \\
\hline & 50 & 195.8 & $Z^{\prime}>0$ & 22.6 & $Z^{\prime} \leq 0$ & -0.8 & 477.7 & $Z^{\prime} \leq 0$ \\
\hline & 100 & 195.9 & $Z^{\prime} \leq 0$ & 21.6 & $Z^{\prime} \leq 0$ & -5.1 & 457.0 & $Z^{\prime} \leq 0$ \\
\hline & 150 & 197.8 & $Z^{\prime} \leq 0$ & 21.8 & $Z^{\prime} \leq 0$ & -4.3 & 467.9 & $Z^{\prime} \leq 0$ \\
\hline
\end{tabular}

CT: Control, DMD: dry matter disappearance, GP: cumulative gas production. 
an observation which is in agreement with the present study.

\section{Effects of essential oils on methane production and apparent DMD}

From the results of this study, addition of most EO at dosages of $300-1200$ or $600-1200 \mathrm{mg} / \mathrm{L}$ caused a significant decrease in methane production per $g$ DM incubated except $Z$. officinalis and $L$. multiflora whose significant negative effects occurred at a more narrowdosage of $1200 \mathrm{mg} / \mathrm{L}$. Consistent with these results regarding $O$. gratissimum, $M$. piperita and $L$. nobilis, Patra and Yu (2012) reported that Thymus capitatus (thymol type), $M$ piperita (menthol type) and Eugenia spp. (eugenol type) inhibited methane production (per g DM) at $250-1000 \mathrm{mg} / \mathrm{L}$. In this trial, $C$. aurantifolia reduced methane production (per g DM). This finding is in line with that of Kamalak et al. (2011) which showed that Citrus sinensis (limonene type), at 200-1200 $\mathrm{mg} / \mathrm{L}$, reduced methane production (per $\mathrm{g} D M$ ). Results obtained with addition of $O$. basilicum are in agreement with Jahani-Azizabadi et al. (2011) which showed that $O$. basilicum (estragole type) reduced methane production (per g DM) at $1000 \mathrm{mg} / \mathrm{L}$. Information relating to effects of $Z$. officinalis (a-zingiberene and ar-curcumene type), $L$. multiflora ( $p$-cymene type), C. citratus (neral and geranial type) and E. citriodora (citronellal type) on methane production is scarce.

The decrease in apparent DMD together with gas production observed in this study suggests that EO may exert a general inhibition on rumen microbial fermentation. The extent of the observed effects of EO on apparent DMD and gas production depended on EO type and EO dosages. This is likely a reflection of the differences in EO composition within plant types (Benchaar et al., 2008; Burt, 2004). The reduction in apparent DMD with $Z$. officinalis and L. multiflora at $1200 \mathrm{mg} / \mathrm{L}$ and with the remaining $\mathrm{EO}$ at $600-1200 \mathrm{mg} / \mathrm{L}$ suggests that beneficial inhibition in methane production is likely offset by adverse effects on rumen microbial fermentation. Effects of $L$. nobilis, $O$. gratissimum, $O$. basilicum, $M$. piperita and $C$. aurantifolia on apparent DMD and gas production as observed in this work are consistent with previous cited studies (Kamalak et al., 2011; Jahani-Azizabadi et al., 2011; Patra and $Y u, 2012$ ) that worked on a range of dietary substrates. To the best knowledge of the authors, there is no study that examined the effects of $Z$. officinalis ( $\alpha$-zingiberene and ar-curcumene type), L. multiflora ( $p$ cymene type), $C$. citratus (neral and geranial type) and $E$. citriodora (citronellal type) on apparent DMD and gas production.

In conclusion, reductions in enteric methane production with limited negative effects on apparent DMD seem to potentially occur in vitro with all EO (except $Z$. officinalis and $L$. multiflora) at dosages close to or less than 300 $\mathrm{mg} / \mathrm{L}$.

\section{Conflict of Interests}

The authors have not declared any conflict of interests.

\section{ACKNOWLEDGEMENTS}

The authors received technical support from Krysty Munns, Darrel Vedres, John Baah, Wendy Smart, Zhongjun Xu and Toby Entz. This project was financially supported by the Canadian Beef Cattle Research Council as part of a program to assess plant extracts that may be used as alternatives to antibiotics, and Benin National Grant Programme for Capacity Building of Trainers.

\section{REFERENCES}

Adams RP (2001). Identification of Essential Oils Components by Gas Chromatography/Quadrupoloe Mass Spectrometry. Allured Publishing Corporation: Carol Stream. USA.

AOAC (Association of Official Analytical Chemists) (2003). Official Methods of Analysis. $17^{\text {th }}$ ed. $2^{\text {nd }}$ rev. AOAC: Gaithersburg. MD.

Baba-Moussa F, Adjanohoun A, Attakpa ES, Kpavodé L, Gbénou JD, Akpagana K, Kotchoni SO, Sezan A, Toukourou F, Baba-Moussa L (2012). Antimicrobial activity of three essential oils from Benin on five oral germs: Test of mouthbaths. Ann. Biol. Res. 3(11):5192-5199.

Benchaar C, Calsamiglia S, Chaves AV, Fraser GR, Colombatto D, McAllister TA, Beauchemin KA (2008). A review of plant-derived essential oils in ruminant nutrition and production. Anim. Feed Sci. Technol. 145(1-4):209-228.

Benchaar C, Greathead H (2011). Essential oils and opportunities to mitigate enteric methane emissions from ruminants. Anim. Feed Sci. Technol. 166:338-355.

Bodas R, Prieto N, García-González R, Andrés S, Giráldez FJ, López S (2012). Manipulation of rumen fermentation and methane production with plant secondary metabolites. Anim. Feed Sci. Technol. 176:7893.

Burt S (2004). Essential oils: their antibacterial properties and potential applications in foods - a review. Int. J. Food Microbiol. 94:223-253.

Canadian Council of Animal Care (CCAC) (1993). Guide to the care and use of experimental animals. ed by Olfert ED, Cross BM, McWilliam AA, CCAC, Ottawa, ON.

Chaves AV, Thompson LC, Iwaasa AD, Scott SL, Olson ME, Benchaar C, Veira DM, McAllister TA (2006). Effect of pasture type (alfalfa vs grass) on methane and carbon dioxide production by yearling beef heifers. Can. J. Anim. Sci. 86(3):409-418.

Cimanga K, Kambu K, Tona L, Apers S, De Bruyne T, Hermans N, Totte J, Pieters L, Vlietinck AJ (2002). Correlation between chemical composition and antibacterial activity of essential oils of some aromatic medicinal plants growing in the Democratic Republic of Congo. J. Ethnopharmacol. 79(2):213-220.

Clevenger J F (1928). Apparatus for the determination of volatile oil. J. Am. Pharm. Assoc. 17(4):345-349.

Fedorak PM, Hrudey SE (1983). A simple apparatus for measuring gas production by methanogenic cultures in serum bottles. Environ. Technol. Lett. 4(10):425-432.

Intergovernmental Panel on Climate Change (IPCC) (2013). Summary for Policymakers. In: Climate Change 2013: The Physical Science Basis. Contribution of Working Group I to the Fifth Assessment Report of the IPCC [Stocker TF, Qin D, Plattner G-K, Tignor M, Allen SK, Boschung J, Nauels A, Xia Y, Bex V, Midgley PM (eds.)]. Cambridge University Press. Cambridge. United Kingdom and New York. NY. USA.

Iscan G, Kirimer N, Kürkcüoglu M, Husnu Can Baser K, Demirci F (2002). Antimicrobial screening of Mentha piperita essential oil. J. Agric. Food Chem. 50(14):3943-3946.

Jahani-Azizabadi H, Mesgaran MD, Vakili AR, Rezayazdi K, Hashemi M 
(2011). Effect of various medicinal plant essential oils obtained from semi-arid climate on rumen fermentation characteristics of a high forage diet using in vitro batch culture. Afr. J. Microbiol. Res. 5(27):4812-4819.

Javari S, Esfahani S, Fazeli MR, Jamalifar H, Samadi M, Samadi N, Najarian Toosi A, Shams Ardekani MR, Khanavi M (2011). Antimicrobial activity of lime essential oil against food borne pathogens isolated from cream-filled cakes and pastries. Int. J. Biol. Chem. 5(4):258-265.

Kamalak A, Atalay Al, Ozkan CO, Tatliyer A, Kaya E (2011). Effect of essential orange (citrus sinensis L.) oil on rumen microbial fermentation using in vitro gas production technique. J. Anim. Plant Sci. 21(4):764-769.

Lassey KR (2007). Livestock methane emission: From the individual grazing animal through national inventories to the global methane cycle. Agric. Forest. Meteorol. 142(2-4):120-132.

López S, Dhanoa MS, Dijkstra J, Bannink A, Kebreab E, France J (2007). Some methodological and analytical considerations regarding application of the gas production technique. Anim. Feed Sci. Technol. 135(1-2):139-156.

Marzouki H, Elaissi A, Khaldi A, Bouzid S, Falconieri D, Marongiu B, Piras A, Porcedda S (2009). Seasonal and Geographical Variation of Laurus nobilis L. Essential Oil from Tunisia. Open Nat. Prod. J. 2:8691.

Menke KH, Raab L, Salewski A, Steingass H, Fritz D, Schneider W (1979). The estimation of the digestibility and metabolisable energy content of ruminant feeding stuffs from the gas production when they are incubated with rumen liquor in vitro. J. Agric. Sci. 93(1):217-222.

Narvaez N, Wang Y, Xu ZJ, McAllister TA (2013). Effects of California chaparral plants on in vitro ruminal fermentation of forage and concentrate diet. J. Sci. Food Agric. 93(3):550-559.

Patra AK, Yu Z (2012). Effects of Essential Oils on methane production, fermentation, abundance and diversity of rumen microbial populations. Appl. Environ. Microbiol. 78(12):4271-4280.

Ribeiro LG, Machado FS, Campos MM, Guimaraes R, Tomich TR, Reis LG, Coombs C (2015). Enteric methane mitigation strategies in ruminants: a review. Rev. Colomb. Cienc. Pecua. 28:124-143.

Satyanagalakshmi K, Sridhar GT, Sirohi SK (2015). An overview of the role of rumen methanogens in methane emission and its reduction strategies. Afr. J. Biotechnol. 14(16):1427-1438.
Secundino L, Makkar HPS, Soliva CR (2010). Screening Plants and Plant Products for Methane Inhibitors. In: in vitro screening of plant resources for extra-nutritional attributes in ruminants: nuclear and related methodologies (Vercoe PE, Makkar HPS, Schilink AC, Eds). Springer Science+Business Media BV. Dordrecht. pp. 192-231.

Van Soest PJ, Robertson JB, Lewis BA (1991). Methods for dietary fiber, neutral detergent fiber, and non-starch polysacharides in relation to animal nutrition. J. Dairy Sci. 74(10):3583-3597.

Wang Y, McAllister TA, Yanke LJ, Xu ZJ, Cheeke PR, Cheng KJ (2000). In vitro effects of steroidal saponins from Yucca schidigera extract on rumen microbial protein synthesis and ruminal fermentation. J. Sci. Food Agric. 80(14):2114-2122.

Wang Y, Xu Z, Bach SJ, McAllister TA (2008). Effects of phlorotannins from Ascophyllum nodosum (brown seaweed) on in vitro ruminal digestion of mixed forage or barley grain. Anim. Feed Sci. Technol. 145(1-4):375-395. 